\title{
Philosopher Niko Chavchavadze: Life and Work
}

\section{Vladimer Luarsabishvili}

Niko Chavchavadze (1923-1997) was one of the most prominent figures of his generation. His major goal was to find new research directions in philosophy. Niko Chavchavadze's philosophical output, his concepts of culture and values, as well as their structure and hierarchy are reviewed. Aesthetics as science is also defined.

Keywords: Niko Chavchavadze, culture and values, Georgian SSR, philosophy

Person should contribute only to such scientific knowledge that obeys and serves moral.

Niko Chavchavadze

\section{Introduction}

It is known that historical valuation of every nation depends on its cultural heritage. The term "cultural heritage" is a wide notion. It means creation of cultural values. The status of cultural nation makes educated and developed

VLADIMER LUARSABISHVILI, PhD (Madrid Autonomous University), professor in Politics and International Relations at New Vision University, Tbilisi; address for correspondence: New Vision University, 1a Evgeni Mikeladze St., 0159, Tbilisi, Georgia; e-mail: vluarsabishvili@newvision.ge

The author thanks Ms. Nana Grigalashvili for an English translation of the article. 
society different from the barbarians. During a long history of mankind, in different epochs, countries created values of different cultural characteristics. Cultural values of the Eastern World and Western countries were alike but at the same time they differentiated from one another. Their similarity was caused by the fact that cultural values were created by educated representatives of the society. Regarding to the difference, it was caused by different geography, history and cultural traditions. The notion of "cultural tradition" refers to cultural characteristics and its anatomical originalities which were created during a certain period of time. Every cultural innovation was an outcome of a nation's cultural traditions. Conclusively, originality was separated from imitation. While imitation was superficial and meant a mechanical copy of other country's cultural traditions (including literary, musical, art and others), originality was such influence of other country when a cultural model of foreign society was combined with own cultural characteristics and thus, developed an original and familiar model of culture. The influence of different culture is especially strong when culture is in critical phase of its development. To study and share different cultural models with your own culture is very big experience. This method has been used for centuries. Western civilization used this method too. It studied eastern cultural points, developed and made them appropriate to its ones. The process of internalization is very important to implant any cultural model in other country.

Culture is made of values which are vital for any culture. They are its anatomical parts. Values create concrete culture and make it separate from another. Culture is described and studied based on them. None of cultural values can be universal or fully relevant to another culture. Differentiation makes culture valuable and important.

There are several ways to create culture. Culture is divided into two different types: material and non-material culture. Material culture refers to the physical objects that can be seen, touch and felt. Non-material culture refers to the abstract ideas and ways of thinking that make up a culture. Unlike material culture, non-material culture is intangible. Difference between material and non-material culture is that while material culture doesn't evolve, non-material culture develops and changes permanently. Moreover, non-material culture determines the development of material culture because individual values create visual effects of cultural objects. 
Conclusively, cultural heritage is heterogeneous by nature. It refers to material and non-material recourse that belongs to a concrete nation and is a result of its development. During describing, studying and appraising cultural heritage it is important to take into consideration those geographical and historical characteristics that are created by a concrete nation.

One of the most important ways to show the existence of culture is thinking which determines formation and development of society in different epochs, showing those values which are the base of the history of that nation. Cultural heritage of different periods are outcomes of thinking. Noteworthy is philosophical thinking and its survey.

Philosophy, or love of wisdom, is an important ability of man's mental power. Russian philosopher Pyotr Chaadayev provided detail review of this issue in his famous text ${ }^{2}$. Presumably, it is not important how much a nation showed its ability of philosophical thinking. It is more important how much a nation could to internalize others' achievements. Defining the notion of "intrahistoria” ("personal history") Spanish philosopher Miguel de Unamuno emphasized the importance of present time during the development of society. According to him, traditions were belongings of present days rather than a past $^{3}$. In result, although society may not be inclined to form philosophical thinking historically, it can be eager to study and realize the experience of forming philosophical thinking. This case a person will be able to contribute to the development, alternation and restoration of philosophical thinking. If we agree that Socrates and Plato ${ }^{4}$ were authors of the first idea, it means that sequence of ideas is very important. This confirms that sequence of ideas is important because it emphasizes the possibility of different interpretations of one idea. When philosophers speak about the issue that is interesting to him, he needs point of reference or ploughed ground to plant seeds in it and gather the harvest. In historical thinking this is achieved through two ways. These are: a) a philosopher grounds his views on those views that were uttered earlier chronologically, and b) a philosopher makes a point of reference for future philosophers and their schools of philosophy. Russian scientist Mikheil Bakhtin's "First Philosophy" that according to Adrian Bertorello ${ }^{5}$, was grounded on the

\footnotetext{
${ }^{2}$ П. Чаадаев, Философические письма, Римис, Москва 2011.

${ }^{3}$ M. de Unamuno, Del sentimiento trágico de la vida, Espasa Libros, Madrid 2011.

${ }^{4} \mathrm{G}$. Colli, El nacimiento de la filosofía, Tusquets Editores, Barcelona 2009.

${ }^{5}$ A. Bertorello, Bajtín: acontecimiento y lenguaje, “Signa” 2009, no. 18, p. 131-157.
} 
thinking of his contemporaries testifies to the first way. Regarding the second way, Aristotele's views about metaphysics which became a subject of survey and discussion for the next generations and schools testify to it ${ }^{6}$. It is very interesting to study the process of the origin, development and changing of the idea. Mirko Lampis called it a systemic thinking (connection between EvenZohar's "Polysystem theory", Edmond Cross's "Sociocritique" and Yuri Lotman's "Semiotics of culture") 7 . Descartes discussed the importance of first idea ${ }^{8}$.

As regards interpretation, noteworthy is that this notion has at least three meanings. The first one is that every philosopher of the following period makes philosophical thinking of his predecessor a subject of interpretation. According to Jose Solana Dueso, Aristotele and Plato read and criticized the tests of their predecessors?.

The second meaning of the interpretation is that philosophers' texts are subjects of interpretation for their translators. Historically philosophical thinking developed through translations and translations' translation from Greek into Arabic, and from Arabic into Latin. Professors $\mathrm{Lisi}^{10}$ and Chico Rico ${ }^{11}$ composed very interesting articles concerning this issue.

The third meaning of the interpretation is that the first meaning of an idea changes as time goes by. The notion of irony testifies to this. In different times it had different meaning ${ }^{12}$.

${ }^{6}$ J. Marías, Ideas de la metafísica, Editorial Columba, Buenos Aires 1954.

${ }^{7}$ M. Lampis, Del texto a la cultura. Apuntes sobre el pensamiento sistémico aplicado a los estudios culturales, "Signa” 2013, no. 22, p. 447-462.

${ }^{8}$ R. Descartes, Discurso del método. Meditaciones metafísicas, Espasa-Calpe, Madrid 1970.

9 J. Solana Dueso, La filosofía griega en el siglo XXI, “Daímon. Revista Internacional de Filosofía" 2010, no. 50, p. 169-178.

${ }^{10}$ F. L. Lisi, La traducción de los textos filosóficos clásicos. En VV.AA., Primer Simposio Internacional Interdisciplinario "Aduanas del Conocimiento". La traducción y la constitución de las disciplinas entre el Centenario y el Bicentenario. Residencia Serrana IOSE, La Falda, Córdoba, Argentina. 8 al 12 de noviembre de 2010, Universidad de Córdoba, Córdoba 2010, p. 1-14.

${ }^{11} \mathrm{~F}$. Chico Rico, La traducción del texto filosófico: entre la literatura y la ciencia, "Castilla. Estudios de Literatura" 2015, vol. 6, p. 94-112.

${ }^{12}$ Concerning this issue, see: W. Biemel, La ironía romántica y la filosofía del idealismo alemán, “Convivium" 1962, no. 13-14, p. 29-48; V. Jankélévitch, L'ironie, Flammarion, Paris 1964; W. Booth, A Rhetorics of Irony, The University of Chicago Press, Chicago 1974; P. Ballart, Eironeia. La figuración irónica en el discurso literario moderno, Quaderns Crema, Barcelona 1994; S. Kierkegraard, De los papeles de alguien que todavía vive. Sobre el concepto de ironía, Editorial Trotta, Madrid 2006; C. Morón Arroyo, La ironía en el Quijote: la maestría de la obra maestra, Actas 
This article is devoted to Niko Chavchavadze as a philosopher. He was a doctor of sciences, professor and director of the Institute of Philosophy. He was one of the most prominent figures of his generation. His major goals were to find new research directions in philosophy, as well as to find young and coming personnel and to assist them to achieve professional success. Besides, noteworthy is Niko Chavchavadze's public activities.

\section{Philosopher Niko Chavchavadze: Short Chronology of Life}

Niko Chavchavadze was born in Kvareli on May 5, 1923. In 1924 his father, Zurab (son of Nikoloz) Chavchavadze was arrested. He was accused of participating in the August Uprising of 1924. Afterwards, events began to develop according to the scenario characteristic of that period - the family members of the detainee were expelled from their own house. For this reason, in the hot summer months, one-year-old Niko and his mother lived in Nasakdrali. Niko's mother was a teacher at a village school. The villagers loved her very much and when she was left without the breadwinner they began to assist her secretly. Although Zurab Chavchavadze was released soon after his detention, in 1929 he was arrested again and sent into exile in the Urals where he died at the age of 36. Niko was six years old when he saw his father for the last time. He remembered well his father's last lesson as follows: When a prison servant took his father in and stopped him beyond iron bars Niko began to cry. Father reprimanded him, saying, "Don't shame me before a Russian soldier's eyes!" Who knows how important this last lesson was to the future philosopher!

When Niko's father was sent into exile Niko, with his mother and grandmother, began to live on Uznadze Street. His family suffered many hardships.

del Congreso Cervantes, El Quijote y Andalucía (Sevilla 6-8 de mayo de 2005), Asociación Andaluza de Profesores de Español, Sevilla 2007, p. 111-136; D. Wolfsdorf, The irony of Socrates, “The Journal of Aesthetics and Art Criticism” 2007, no. 65, p. 175-187; M. Á. Garrido Gallardo, IRONÍA. Gran Enciclopedia Cervantina ed. by C. Alvar, VII., Castalia, Madrid 2010. 
Later, Niko Chavchavadze recalled that they didn't have spare clothes and for this reason, when his mother washed them they had to wear wet clothes.

In 1941 Niko Chavchavadze went to war voluntarily. He received thirteen wounds. In September of 1944 he came back to Tbilisi. He graduated from the Faculty of Philosophy of Tbilisi State University. In 1949 he started to work as a junior scientific worker at the Institute of Philosophy. Since then Niko Chavchavadze connected his life not only to the Institute of Philosophy, but also the essence of the philosophy. Thus, the philosophy became indivisible part of his life and formed the main points of his ideology.

The second part of my article provides the survey philosopher Niko Chavchavadze's ideology and his scientific inheritance. This part consists of three subparts. In the first we will try to survey Niko Chavchavadze's beliefs concerning moral, inner freedom and truth in connection with history, politics and scientific-technical progress; the second provides the survey of that administrative and creative way that the Institute of Philosophy of the Georgian National Academy of Sciences passed between 1966 and 1997 when Niko Chavchavadze died. This part also provides information about his public activity, and the third provides the survey of Niko Chavchavadze's philosophical inheritance. We will discuss the concepts of Culture and Values, as well as Structure and Hierarchy. Besides, we will define Aesthetics as a subject of science.

\section{Philosophy, Scientific-Technical Progress, Moral and Inner Freedom}

In order to learn Niko Chavchavadze's world view it is very important to study those metaphysical connections that he defined between structures of thinking. It is obvious that for him, as for the scientist, scientific research was a crucial factor. However, not only deep thinking made Niko Chavchavadze different and original creator, but also ability to internalize and make it part of himself. He managed it through sharing education.

In 1984 the Institute of Philosophy made scientific contacts with American colleagues. The initiators of cooperation were American scientists. For this reason, their delegation paid a visit to Tbilisi. Although the Committee for State Security didn't approve the meeting of Georgian and foreign colleagues, Niko Chavchavadze applied to his ability of solving problems and the meeting 
took place. In consequence of this meeting, those base points that were naturalized in science and everyday life by Niko Chavchavadze took shape more vividly.

The meeting that took place in 1984 laid the foundation for future cooperation. First, that caused astonishment of American scientists was that the subject and the direction of scientific researches of the Institute of Philosophy of the Georgian National Academy of Sciences didn't coincide with the research subject of the Institutes of Philosophy in other Soviet states. Moreover, they were radically different from one another. It seemed that philosophers of two countries easily found a common language. In result, in 1988 the head of the U. S. Institute of Peace and Mutual Understanding, Mr. Paulpeach, suggested Georgian colleagues drawing up a treaty with the Catholic University of Washington. The point was that the Research Institute of Philosophy of the Catholic University of Washington and the Institute of Philosophy of the Georgian National Academy of Sciences were alike. The parties planned the first joint project. They were to work on a theme "A person in different society".

Joint working program consisted of tough academic schedule. The parties were to hold joint annual conferences in America and Georgia in turn. Besides, a five-year plan was to be carried out. Within the framework of this plan, the parties were to organize exchanging programs for researchers, including students, post-graduate students and scientific workers, no matter of their level of education. The subjects of the first conference were to be one of the oldest problems in philosophy. These were: knowledge and moral. These issues were still relevant in the late $20^{\text {th }}$ century. As Niko Chavchavadze noted, while knowledge went ahead, moral fell behind.

Below is presented a brief review of the first conference subject. We think that the American, as well as the Georgian scientists didn't choose this subject by chance. Science always reflects modernity and studies the challenges facing the public. At the end of the $20^{\text {th }}$ century significant historical and political changes took place. Consequently, the Soviet Union was dissolved. This fact made influence not only on the scientific and cultural development of the postSoviet countries, but also on the intellectual and economic development of many countries throughout the world. Georgia was not an exception. 
In any era man's action was determined by the factor as follows: how he perceived the existing reality. Perception of the existing reality is especially important when society lives in a double reality that is characteristic of the totalitarian regime. The members of a non-democratic society live in genuine reality in parallel with artificial one. The latter is inspired by agitation and propaganda. This kind of reality existed in the Soviet Union. It was fabricated, written on paper (newspapers, journals and leaflets) and non-existent. While according to Plotinus, perception of reality was inclined to transcendence, which consisted of three components: knowledge, ethic and aesthetics, that in result made it possible to have the mystic vision, according to Soviet society, perception of reality was made-up. In other words, Soviet citizen didn't try to study the existing reality. She/he fabricated, drew and painted it in gay colors. Consequently, knowledge, ethic and aesthetics were separated from one another in Soviet reality. They were not connected in scientific or everyday life. For this reason, noteworthy is the studies of the Institute of Philosophy of the Georgian National Academy of Sciences. Niko Chavchavadze was an inspirer and head of these studies.

According to Niko Chavchavadze, philosophy can only inspire, explain and give arguments ${ }^{13}$. Talking about the value of scientific knowledge he stressed the importance of moral. We didn't give the sample of the Soviet system by chance. Niko Chavchavadze thought that while the Soviet Union was built on the alleged scientific knowledge, moral was absolutely ignored during its existence. If there was a gap of moral in the society it should be filled. According to Niko Chavchavadze, philosophers should contribute to it. For this reason, it was very important that philosophers' works to be interesting not only to the specialist, but also to the wide range of readers. He said that Zurab Kakabadze, Tamaz Buachidze and Gia Nodia had very interesting letters ${ }^{14}$.

Discussing the importance of scientific-technical progress, it was noted that modern science was formed when man shifted its attention from a question "What?" to a question "How?"15. Niko Chavchavadze meant this when he discussed the problems of thinking not only in the Soviet Union, but also in the Western world. Increasing the role of technics made man extra element of

\footnotetext{
${ }^{13}$ N. Chavchavadze, Let us not stay bolts, “Tbilisi” 1990, no. 183 (11302), p. 5.

${ }^{14}$ Ibidem.

${ }^{15} \mathrm{X}$. Арендт, Между прошлым и будущим. Восемь упражнений в политической мысли, Издательство Института Гайдара, Москва 2014, p. 87.
} 
technological progress. Niko Chavchavadze (as well as Plotinus) deemed that ethical norms and moral should become a key point. According to him, deficit of ethics and moral in our country was caused by historical background, and in particular, by the October Revolution and its consequences. The Communist regime caused not only material, economical and historical problems, but also the values deficit. People lost inner belief and independence. They gained slavish thinking and lost the ability to feel aesthetic. Niko Chavchavadze reviewed these historical factors when he talked about losing inner independence and the importance of its maintenance.

His discussion covered the issue as follows: the conflict between truth and politics. It is known that this conflict arose when the lifestyle of a philosopher and citizen opposed. Naturally while a citizen's attitude toward truth changes in parallel with the development of civil values, the truth is associated with eternal points for the philosopher. Due to the fact that these points are eternal, they can form such principles that later will lay foundation for civil behavior. In any case, the history of the nation will be a mix of citizen's and philosopher's experience. When Niko Chavchavadze reviewed these issues he noted that "The history of a nation is a history of its culture, including material and spiritual ones (Spiritual culture refers to art, politics and social filed). Culture is created by individuals. Individuals, of course, use people's wisdom but culture is expressed and created by individuals. For this reason, our history is a history of Shota Rustaveli, Ilia Chavchavadze and others ${ }^{16}$.

This is very interesting shift from the issues of history, politics and truth to the issue of individual. The latter and the issue of independence are indivisible. According to Hannah Arendt, the issue of independence is very important for studying the issue of politics because none of political theory can ignore the fact, that without independence we find ourselves in a deep forest and philosophy can't find its way ${ }^{17}$. Presumably, Niko Chavchavadze wanted to study the issue of inner independence when he noted that the role of individuals was very important for the history of a nation. Inner independence is a space where person feels free and which does not have physical expression (For this reason, it

${ }^{16} \mathrm{~N}$. Chavchavadze, I don't have a right not to be an optimist, "Kvareli” 1989, no. 100 (6108), p. 2 .

${ }^{17}$ Х. Арендт, Между прошлым и будущим. Восемь упражнений в политической мысли, Издательство Института Гайдара, Москва 2014, р. 220. 
is not directly connected with politics). However, it is man's one of late acquisitions because he decided to escape from the place where there was no longer independence. Thus, he decided to create the world where nobody would be able to take away his independence, and moreover, nobody would be able to enter there. It is paradoxical that a person who escapes from the society and stays alone with his independence creates material and spiritual works for the society which he left. Philosopher Niko Chavchavadze thought that writer Ilia Chavchavadze was such person.

In one of the interviews Niko Chavchavadze quoted a French philosopher Sartre who said that the only thing man couldn't get rid of is freedom. Philosophers got interested with the issue of freedom when it was no longer referred to as human action (According to Epictetus, freedom is when a person does what he likes), but as a form of attitude towards yourself. From philosophy before Socrates till Neoplatonism freedom was not a subject of philosophical study. Freedom's becoming concept of philosophy is connected to Christianity, and in particular, with the names of Paul the Apostle and St. Augustine. It was a time when freedom was not dissociated from politics. Since then freedom has been expressed in action. Man becomes free if he acts. Therefore, the notions of freedom and action have one meaning.

Scientists of the $20^{\text {th }}$ century dedicated important studies to the subject of freedom. Existentialists are noteworthy among them. This period of the development of philosophy is very important to solve one problem. This is as follows: There has been an argument about which science, philosophy or literature, was first since they dissociated from one another.

In modern western scientific periodicals, and particularly in the journals of philosophy, as well as theory of literature and comparative literature, the subject of key interest is connection between philosophy and literature not only during studying the works of individual authors, but also during reviewing theory of literature, as well as movements in literature and epochs. Noteworthy are recent studies concerning establishing presumable connections between universal movement in literature of the $19^{\text {th }}$ century - Romanticism and philosophical doctrine of the $20^{\text {th }}$ century - Existentialism. As it turns out, both 
aesthetics have common specifications, and both of them are under the influence of, neither more nor less, the Neoplatonic vision ${ }^{18}$.

When we try to analyze Niko Chavchavadze's philosophical vision, automatically we remember abovementioned two movements. We mean as follows:

It is known that romanticists live at the edge of two realities. One of them is factual, in other words, it is reality where an author was born, grown up and writes. The other one is fiction. This reality is viewed only by the author and is in his imagination. Very often these two realities are so much interwoven that it is difficult for the author to separate them. Therefore, he lives in both of them being at their border. The reason why the author creates fiction is that he wants to escape from the society that turned its back upon him and didn't make him worth of being its member. In this case the author doesn't try to find a way out of this situation in real world. On the contrary, by and by he becomes addicted to fiction. This is all about romanticism.

There is similar aesthetics in existentialism. An author concentrates on himself because outward world is not interesting to me. In contrast with romanticist, existentialist can get interested in finding a way out of the difficult situation in real world that is not in his domus interior. It makes romanticist different from existentialist. While the first doesn't try to find a way, it is the main goal to the other.

Romanticism, as well as existentialism, is based on what Niko Chavchavadze noted was necessary to study. It is necessity to obtain inner freedom. Romanticist needs it to be in the center of the world and forget himself. He achieves it through romantic irony. Existentialist needs inner freedom to show his advantage and to find a way of life. He achieves it through existential irony. According to Niko Chavchavadze, history of a nation and its culture is created by such individuals. These are people who society turns back upon them but who work for this society. Niko Chavchavadze's goal was to instill the ideology of Platonism and Neoplatonism in everyday life and make it relevant to the existing reality.

${ }^{18}$ C. Guillén, De influencias y convenciones, 1616, "Anuario de la Sociedad Española de Literatura General y Comparada” 1979, vol. II, p. 87-97; J. M. Del Pino Cabello, Algunas observaciones sobre el neoplatonismo becqueriano, "Dicenda. Cuadernos de filología hispánica" 1986, no. 5, p. 91-101; C. Moreno Hernández, Notas sobre Bécquer: Materialismo y Romanticismo, "Castilla. Estudios de literatura" 1987, 12, p. 95-106; V. Luarsabishvili, La sensación de la soledad en las Rimas de Bécquer (Aproximación a la poesía metafísica), "Revista de filosofía” 2017, no. 42 (2), p. 247-259. 
Niko Chavchavadze made his views about truth, politics, moral and inner freedom the main research subject of the Institute of Philosophy. Consequently, such scientific views were developed in the institute which were absolutely unacceptable to the society in that period. Scientific workers of the institute studied philosophical anthropology, as well as philosophical issues in culture and values. These movements were against scientific views of that time. For this reason, Soviet authority deemed the Institute of Philosophy to be an asylum for non-Marxists and thus, persecuted it.

It was very important to Niko Chavchavadze to conclude scientific research, but also to make its results accessible to the society. For this reason, his lectures and works were not rich in scientific terminologies. He thought that philosophical issue of any difficulty could be explained with simple words. For this reason, he thought that the contribution of individuals was very important to historical processes and charged them with responsibility to act in decisive and critical situations.

It is known that one of the most important symptoms of crisis is its expression in the fields of upbringing and education ${ }^{19}$. In this aspect, the notion of authority is very important. This term is derived from Romanian and it is not known in the Greek culture. Although the Greeks are rich in political culture, despotic and tyrannical power that were characteristic to them could not be acceptable to a free man, because authority is such type of obedience when man stays free. In contrast with the Greeks, according to the Romanians, having authority excluded having power (Cicero said that people possesses the power but the Senate has the authority). Such authoritative persons play a crucial role in the development of society in critical situations. Although concrete individuals don't have the power, they offer fellow citizens an action plan. Niko Chavchavadze meant them when he spoke about the individuals who should assume responsibility to liberate the nation. Niko Chavchavadze himself contributed to this not only in the Institute of Philosophy, but also in the society. His life and scientific works made him an authorized person who didn't have the power. However, he was always in the foreground of public events and played a crucial role in forming public opinion.

The issue of the authority is directly connected with the issue of the truth which is counterpart of a lie. It is known that the truth and a lie are two sides

\footnotetext{
${ }^{19} \mathrm{X}$. Арендт, Между прошлым и будущим. Восемь упражнений в политической мысли, Издательство Института Гайдара, Москва 2014, p. 139.
} 
of the medal. The thing that is the truth now, later it can be a lie. Totalitarian systems testify to this. If we divide Soviet period into sub-periods, it will turn out that the truth of each next sub-period is radically different from the truth of previous one. Appraising politicians, as well as philosophers, is similar to this. Different publications of Soviet history appraise the ideologists of the Soviet regime differently. According to different volumes of Soviet history, Trotsky, Bukharin, Rykov, Beria and Stalin play different and absolutely discordant roles. The reason is that the reality is not a mechanical complex of the facts and movement of time. Perception of reality differs in different epochs. The abovementioned Soviet authorities were appraised differently in Soviet period. It is not surprising if their appraisal changes after some time. For this reason, a person must be studied in one concrete moment of the history taking into consideration his contribution to the development of the country.

The history appraises differently not only politicians, but also philosophers. Everybody knows how Rousseau, Voltaire and other philosophers were appraised when they were alive. It can be explained by the fact that unlike politicians who have the power, philosophers possess the authority which is not less valuable.

Next subchapter provides the study of Niko Chavchavadze when he worked in the Institute of Philosophy. Besides, we offer the review of the situation he made in the institute and try to analyze the results of a scientific and public order that was instilled by him in the Georgian scientific life in the $20^{\text {th }}$ century.

\section{The Institute of Philosophy and Public Life: New Perspectives}

In 1966 Niko Chavchavadze was appointed as the director of the Institute of Philosophy of the Georgian National Academy of Sciences. He began to renew a scientific course of the institute. New creative impulse was spread throughout the institute that was, by all means, Niko Chavchavadze's merit.

In Soviet period different branches of science developed differently. Communist regime supported the development of those branches that served the consolidation of this regime and its popularization among the people. However, these branches didn't meet modern European demands. As for the other 
branches of science, which were important for the development of free thinking and thus, unacceptable to authority, were behind of those branches that were supported by authority. Humanitarian and social sciences were in the black list. Philosophy was not an exception.

It is natural that philosophy which historical development is connected with the study of such issues as are: freedom, religion, politics, ethics, aesthetics and so on, was strictly controlled by Soviet ideologists and censors. Its development, as well as a slight infraction was absolutely excluded. It must be surprising to the modern scientists and readers that in Soviet reality of the 20th century science was to be developed according to the plan. A new initiative and a slight change was impossible and considered to be a crime. For this reason, changed interpretation of Marx's theory was the only course that was instilled by the All-Union Institute of Philosophy. The readers were to be convinced that western philosophy was absolutely wrong and they were to be grateful to the Soviet authorities. In such situation it was totally impossible to cultivate free thinking, as well as to develop creative process and cooperate with foreign colleagues.

There was not creative freedom in the Soviet Union. Besides, the level of scientific thinking was very low. It was impossible to keep the family for the ordinary scientific worker with his monthly salary if he was not a head of the department or official of higher rank. Consequently, the staff of the scientific institutes consisted of the persons who didn't succeed in other fields and started to work there on full-time or half-time with the help of their contacts. There were also such collaborators who "worked" in the research institute and at the same time had two or three other working places. It is not surprising that the institutes that had such staff served authority that didn't wanted to develop free and creative thinking that would be different from an official ideology. The Institute of Philosophy in Georgia was not an exception. This was a situation in the institute when Niko Chavchavadze began to work there.

Niko Chavchavadze, as the director of the institute drew up and realized a two-stage plan. At first he determined a new research course. Afterwards, he selected the staff that would realize his plan. Noteworthy is that the second part of the plan - selecting creative collaborators, was a permanent process. During those years when he was a director of the institute he permanently hired scientific workers who would be useful not only for the realization of a scientific 
plan of the institute, but also for the accomplishment of on-going projects. T. Mtibelashvili recalled this period very interestingly. He said:

"Late period of the Georgian philosophy of culture can't be reviewed without mentioning Niko Chavchavadze's (1923-1997) merit in its development. He was not only a famous philosopher and researcher, but also a big public figure who had broad interests. His merit is mainly connected to the period when he was a director of the Institute of Philosophy of the Georgian National Academy of Sciences which was the most important center for studying the problem of philosophy of culture. He worked in the institute from the second part of the 1960s until his death in 1997. At his initiative and with the help of leading specialists of the institute, at the end of the 1960s and at the beginning of the 1970s the priorities of research activity of the institute became philosophical problem of man, culture and value. It was considered that their study was the most important and useful method for the development of this field"20.

In conclusion, new research subjects were determined. It was decided to study philosophy of culture, as well as its inner and related branches. The review of this issue is presented in the third sub-chapter which provides the information about Niko Chavchavadze's scientific inheritance. Below we present the review of his human and administrative abilities.

Before we discuss Niko Chavchavadze's administrative activities, let's review the period when Niko Chavchavadze worked in the Institute of Philosophy but he was not a director. In 1949 he became a scientific worker of this institute. He was an active public figure and got involved in the fight for reappointing Savle Tsereteli (who was very dear person for him) in the institute. Tamaz Buachidze recalled these years as follows: "In 1949 Niko became a scientific worker in the Institute of Philosophy. He didn't have a peaceful life. He fought for reappointing his dear person and a famous philosopher Savle Tsereteli as the director of the institute"21. Accordingly, Niko Chavchavadze didn't start public activity after becoming the director of the institute. It was a part of his character which became clearer when he assumed responsibility.

${ }^{20}$ T. Mtibelashvili, Philosophy of Culture, In the collection: The History of the Georgian Philosophical Ideology, IV, Tbilisi 2003, p. 424.

${ }^{21}$ T. Buachidze, A Genuine Intellectual, In the collection: Philosophical Essays, II, Tbilisi 2005, p. 648. 
In any Soviet state (Georgia could not be an exception) on the way of its development it is very difficult for the head to select new and educated staff. In decisive moment when there was a possibility to renew everything, it was very important to renew scientific energy. The Georgian Institute of Philosophy, under the leadership of Niko Chavchavadze, had to pave the way that had already been passed by the Tbilisi State University. Alike to Ivane Javakhishvili and his like-minded persons, Niko Chavchavadze and his colleagues started to select new personnel and thus, to renew human resources of the institute. Tamaz Buachidze recalled this period as follows:

"Let's remember the period of the Institute of Philosophy when its director was Niko. The director of the institute loved freedom. For this reason, he selected those persons in the institute who loved freedom and philosophy. The following persons started to work in the institute: Givi Margvelashvili, Givi Orjonikidze, Rezi Tvaradze, Merab Mamardashvili who came from Moscow, Mamia Bakanidze who came from Alma-Ata and others... They worked on the problem that was interesting to them. For this reason, the institute was called "Oasis of Freedom". It was a merit of the director of the institute"22.

Niko Chavchavadze was like to those persons who were happy with other's talent and gave them stimulus to work. He was like those professionals who were sure of their knowledge and didn't consider future generation to be their competitors. In Soviet period many successful scientists hindered the development of future scientists. Professors often restricted the fellow workers in work and made them do black work. They were not satisfied with their work and thus, didn't give them opportunity to work independently. Niko Chavchavadze was absolutely different from such professors. The goal of his administrative activity was opposite to this. His goal was to find and support talented fellows. According to Revaz Balanchivadze, "He was very talented and was very happy when he saw that other person was talented too. Many famous scientists were found by him. His recommendation was very important"23.

International scientific authority helped Niko Chavchavadze to support the development of fellow scientists. Not only personal charism, but also logical thinking helped Niko Chavchavadze to expose pseudo-phycologists who

${ }^{22}$ Ibidem, p. 645.

${ }^{23}$ R. Balanchivadze, "A Genuine Philosopher/Academician Niko Chavchavadze/", In the collection: Philosophical and Publicistic Letter/ Greetings, Memoirs/, Publishing house "Universal", Tbilisi 2011, p. 174. 
were close to the officials and to defeat them in scientific discussions. Balanchivadze said: "Niko Chavchavadze had big authority among Georgian and foreign philosophers. I myself attended many international and all-union (the author means "the Soviet Union") scientific conferences where Niko Chavchavadze defeated many party workers and philosophers who were close to the officials in the discussion. High culture of thinking, tough logic, excellent taste and his personal charm made others have sympathy towards him"24.

Noteworthy is that Niko Chavchavadze was looking for talented fellows not only in the field of philosophy, but also in relevant fields which laid the foundation for the development of many scientific branches. Balanchivadze recalled: "Mr. Niko was a great friend of young people. He worked with students, aspirants and young scientific workers enthusiastically. He listened and shared their ideas with pleasure. He looked for and selected talented people. Very often he drew over especially talented persons from other fields. Mr. Niko formed a strong army of free thinking philosophers and especially aesthetes, axiologists and culturologists throughout the republic"25.

Noteworthy is a story concerning Tamar Chkheidze. A famous Georgian dissident Tamar Chkheidze was strictly controlled by authority. She was isolated from the society for her active public position many times. She could not work in Tbilisi. For this reason, when she graduated from the university she was sent to work far from the capital. Niko Chavchavadze helped her. Balanchivadze said:

"Tamriko Chkheidze was considered to be "different thinking". She hindered authority and it was decided to isolate her from the society as "an extremely dangerous" element. Niko Chavchavadze was the only person who wanted to defend and take her to the institute (He came to me as I was an assistant of Mr. Eduard Shevardnadze and asked me to inform him that he wanted Tamar Chkheidze to become his collaborator. I, of course, performed his request)"26.

However, he didn't renew the personnel at the expense of young workers. Many professors who were famous and experienced researchers in their fields became leading scientists of the Institute of Philosophy. Among such persons was academician Angia Bochorishvili. When he left the Georgian Academy of

\footnotetext{
${ }^{24}$ Ibidem, p. 173.

${ }^{25}$ Ibidem, p. 174.

${ }^{26}$ Ibidem, p. 180.
} 
Sciences he started to work at the Institute of Philosophy. He started to study philosophical issues of psychology.

"Academician Angia Bochorishvili was a vice president of the Georgian Academy of Sciences. In 1961 he left the Academy of Sciences and opened new department in the Psychological Institute. However, he had to oppose leading professors of the institute concerning mental problem of in-consciousness. It became necessary to clear the atmosphere. Niko Chavchavadze, who was a deputy head of the Institute of Philosophy, used the chance and transferred not only Mr. Angia, but also his whole department to the Institute of Philosophy. Those who knows Mr. Angia Bochorishvili's works agree that his place was in the Institute of Philosophy because the main topic of his study was philosophical problems of psychology"27.

Naturally, authority noticed Niko Chavchavadze's activity and didn't like it. The Central Committee of the Communist Party of Georgia formed a checkup committee. The committee was to check on-going activities of the Institute of Philosophy of the Georgian Academy of Sciences. Revaz Balanchivadze described this period as follows: "It seems that authority was so much irritated by Mr. Niko's dissident activities that it was decided to punish him. The Central Committee formed a committee which consisted of several persons. Their goal was to hinder Mr. Niko. The process of checking which was headed by a deputy manager of scientific department of the Central Committee of the Communist Party lasted for several months. The institute became paralyzed. The managers of the departments and ordinary collaborators of the institute were interrogated applying to the chekist methods. The situation was extremely tense. The worst thing was that nobody asked anything Mr. Niko. He was not allowed to attend the interrogations of his collaborators or to read their interrogations later.

Finally, the check-up process was over and the committee convened a meeting of the institute to announce its conclusion. News was spread that the meeting of the institute would be attended by the First Secretary of the Central Committee Eduard Shevardnadze. Tense situation reached its peak. It was clear that the committee would not mercy Mr. Niko (They could make up a story. Nobody was interested in the truth). Everybody knew well that Mr. Niko was absolutely right. However, nobody knew the position of the First Secretary of the Central Committee. 
Eduard Shevardnadze attended the meeting. "Prosecutors" read their indictment. Noteworthy is that the personnel of the institute was unanimous, principle and fearless. They scolded a manager and a deputy manager of the department for sciences of the Central Committee. Eduard Shevardnadze realized that the institute was very monolithic, inaccessible and firm. He realized that he should defend Niko Chavchavadze against the department manager of the Central Committee.

This day was very important not only for the institute, but also for Niko Chavchavadze and even Eduard Shevardnadze. The institute became famous because it could defend its interests under the communist regime. Eduard Shevardnadze became famous (especially among scientific and creative intelligentsia) as a fair leader and a friend of the intelligentsia. As for Mr. Niko, he became more known as a brave and principle man. Besides, he became Eduard Shevardnadze's friend"28.

Noteworthy is how Tamaz Buachidze remembered these events. He recalled a meeting of Central Committee Bureau of the Communist Party of Georgia. The check-up results were reviewed at the meeting. The speaker reported about those ideological mistakes that were made in the Institute of Philosophy. He charged its director, Niko Chavchavadze with responsibility. The report made by a guest from Moscow was alike to this.

It was noteworthy for the committee that among many researches that were conducted in the institute, Noe Zhordania's philosophical thinking was studied too. The director of the institute was given opportunity to answer back. Tamaz Buachidze described Niko Chavchavadze's report very interestingly and deeply. Niko Chavchavadze's tough logic and personal charm made the most members of the committee change their mind. The institute came through the personnel reduction or who knows, its closure, and its administration - repressions. Thus, the Institute of Philosophy stood up one more attack and continued functioning as usual.

"I hardly remember the meeting of the bureau of the Central Committee that reviewed the activity of the Institute of Philosophy. I remember the reporter speaking confidently but unwisely about our "ideological mistakes". He demanded to change the head of the institute. A guest from Moscow had the same pathos. Although he didn't demand to quit the director of the institute, he spoke much about ,ideological collapses”. By the way, one of the scientific

\footnotetext{
${ }^{28}$ Ibidem, p. 180-181.
} 
work concerning Noe Zhordania's philosophical views was considered to be such "collapse". Although his views were criticized in the work, it was deemed to be "ideological deviation". It seems that it was crime to mention Noe Zhordania's name.

The final word was given to Niko Chavchavadze. It's pity I couldn't record our director's speech. It is not exaggeration to say that it was a brilliant report. Niko spoke calmly. He proved that most of the arguments made by the opponents were absurd and ungrounded. Niko managed to make situation free and funny at the meeting of such "serious" and depressed people. Smile grew into laughter on many faces. Niko's speech convinced many participants of the meeting that the arguments of the institute's controllers were pygmies and nonsense. They saw Niko's talent, as well as accuracy and depth of his view, his fantastic sense of humor, and on the whole they saw that he was a genuine member of the intelligentsia"29.

This subchapter provided a brief information about Niko Chavchavadze's executive talent and the atmosphere which made the Institute of Philosophy of the Georgian National Academy of Sciences different and notable scientific home in the Georgian SSR. However, Niko Chavchavadze was not only a philosopher, but also very good public figure. For this reason, we would like to discuss his public activity too.

Niko Chavchavadze established a strict scientific order in the institute with the help of his personal character. It was clear that free and creative atmosphere at work would lay the foundation for the same public activity. It is very interesting to study Niko Chavchavadze's public activities and his political views because any person's action is inspired by inner and outward factors. We would like to draw the reader's attention to such outward factors.

Let's follow the chronology and listen to Niko Chavchavadze who was first, a candidate of deputy and then a member of the Parliament.

Niko Chavchavadze participated in the election of the Supreme Council of the Georgian SSR. He stood for the electoral district no. 219. Marine Zaalishvili took an interview from him. The interview was covered by the newspaper "Kvareli", fall edition no. 100 (6108) which was published by the Regional Committee and Regional Council of Public Deputies of Kvareli of the Com-

${ }^{29}$ T. Buachidze, A Genuine Intellectual, In the collection: Philosophical Essays, II, Tbilisi 2005, p. 646-647. 
munist Party of the Georgian SSR. Niko Chavchavadze spoke about several issues. These were: the action conducted by the Supreme Council of the republic before election, parliament in Georgia, committee for the study of the April 9 Tragedy, and his optimistic character.

Niko Chavchavadze thought that the Supreme Council of the republic should perform its duty and rule the country. For this reason, it was necessary that the personnel of the council were elected by the people and the personnel were to keep their promises given to the people:

"The Supreme Council of the republic should become a real Supreme Council of the republic. It should be a head of the country and its patron. Our council will be able to perform it if it consists of those deputies who are selected by the people and if the deputies keep those promises that were given to the people before the October Revolution by the Communist Party. This is what the Communist Party promised the people: When we come in authority we will give the power to the councils, the land - to the peasantry, and factories to the workers. However, it has not been done yet. Now it is high time the Communist Party kept its promise. Besides, the council must try harder to take power, give the lands to the peasantry and factories - to the workers, and thus, to create a real human and constitutional state"30.

As for the parliament, Niko Chavchavadze thought that in spite of the fact that we didn't have political experience, it was possible to establish this system in Georgia. Its main base should be future generation. "Although we are inexperienced in politics, I know the young people very well. I have been teaching in the university for forty years. There are so educated fellows that I think nothing is impossible" 31 .

As for the activity of the committee for the study of the April 9 Tragedy, Niko Chavchavadze noted that the committee had not accomplished its task yet. He had hope for the committee of the deputies of all-Union: "The committee of Georgia has not finished its work yet because we didn't have contacts with the Kremlin. Fortunately, the Committee of the Deputies of All-Union which partly consists of decent persons have contacts with the Kremlin. They promise us (and I know that it is not false promise) that they will help us to accomplish the task and expose those who were the initiators of this villainy"32.

\footnotetext{
${ }^{30} \mathrm{~N}$. Chavchavadze, I don't have a right..., op. cit., p. 2.

${ }^{31}$ Ibidem.

${ }^{32}$ Ibidem.
} 
At the end of the interview the journalist said to Niko Chavchavadze that his answers were very optimistic. Niko Chavchavadze answered: "I love my elder son Zurab. Of course, I love my younger ones too. One day Zurab came to me and said: "Father, you are a clever man. How can you be such an optimist at the same time?" I answered him: "Zurab, my son, do I have right not to be an optimist?"33.

The candidate for deputy, Niko Chavchavadze, finished his interview with such interesting answer. Below we present the review of his second interview. This time Niko Chavchavadze was a member of the parliament. He gave the interview to the journalist of the newspaper "Iveria Express" Tamar Tsilosani.

This interview with Niko Chavchavadze provided his review about ongoing events of the national-liberation movement. He noted that it consisted mainly of two different wings. He said: "Two wings of the national-liberation movement have become more active during the last few years. Their perception of the reality differs from one another and thus, their point of view concerning future plans is different. While the radical wing was for gaining political independence and then, taking care of the rest, the other wing thought that we should gain independence step by step. Its main goal was to prepare people for the independence morally and first reach economic and cultural independence and then - political independence. Ilia Chavchavadze's society which was the first legal informal society supported the second course" 34 .

Niko Chavchavadze reviewed both of these courses in detail. He grounded with historical experience that the second course was better. According to him, the reason why some countries lost their independence gained after World War II soon was that they chose the first course. He said: "Historical experience shows that it is not right to gain first political independence and then cultural and moral ones. Although many countries declared independence after World War II, soon their independence was found out to be the myth. These countries were not strong economically and they depended on other countries. We declare independence. However, the imperial forces make us do whatever they like. What did they use? They used the fact of the economic

${ }^{33}$ Ibidem.

${ }^{34}$ Idem, One round of the fight for the national-liberation movement failed, "Iveria Express" 1994 , no. 30 (251), p. 2. 
degradation and ethnic conflicts on our territory. Everybody knows that autonomies in Georgia are bombs sent by the empire" 35 .

According to Niko Chavchavadze, its reason was the lack of inner independence which should be gained and not given. He said: "We, the Georgians wanted to change everything around us but we themselves stayed the same. Who will liberate us if we themselves don't become free? If somebody liberates us we will depend on him, won't we? I exaggerate a little but we grew fighting for the independence into demanding the independence. Who can give us independence if not the god and we themselves?"36.

One of the most important dates of modern history of Georgia is April 14, 1978. This was a day when the constitutional status of the Georgian language was to be decided. A new project of the constitution was discussed in the institutions. People held demonstrations to defend the Georgian language. The members of the Supreme Council had to face this problem too. On April 14 a session was to be held. The meeting was opened by Eduard Shevardnadze. Niko Chavchavadze was in the first row. Many demonstrators gathered around the building and their exclamations could be heard in the hall. Niko Chavchavadze sent the presidium of the meeting cards, saying: "Can't you hear the noise of the people? It's high time we came to the people. We must save our language and our country". Shevardnadze finished his report and announced a break. Niko Chavchavadze came out to the demonstrators. He came back to the conference hall last. He was very pale. He repeated several times: "We survived! We survived! We survived! Celebrate, people!".

One of featured cases of that period was an attempted aircraft hijacking by young Georgians. However, their attempt failed. The hijackers were tried by the Soviet Georgian court. The convicts were sentenced to death. The Georgian public figures made a petition and asked the Georgian government to mercy the condemned. After some time most of the subscribers took back their petition. Niko Chavchavadze was among those few patriots who didn't change their decision and asked to mercy the convicts. His words became widely known: "Nobody has right to deprive me of the responsibility for my will".

On December 3, 1996 a meeting of the "Round Table" of the representatives of the Georgian and Abkhazian intelligentsia was held. According to the document which was drawn by them, both sides realized that the reconciliation

\footnotetext{
${ }^{35}$ Ibidem.

${ }^{36}$ Ibidem.
} 
of the Georgians and Abkhazians depended on these people. Niko Chavchavadze and Zurab Achba were among those who subscribed the document. Later, Zurab Achba was assassinated. When Niko Chavchavadze died his family received a condolence letter from the Abkhazian intelligentsia.

Two weeks before the death Niko Chavchavadze participated in the Georgian-Abkhazian meeting in Austria. In his conclusive report he said: "Abkhazians want to cooperate with us. For years they had been said not to speak or contact with Georgians. There would not have been war if it had not happened. We saw that they want to contact with us. It means a lot. The ice began to melt. If this ice doesn't melt we won't be able to solve this problem peacefully".

Niko Chavchavadze was an active public figure and a fighter for the moral and commonwealth of the people. Next subchapter provides the survey of Niko Chavchavadze's philosophical inheritance, as well as his scientific ideology and a research subject which was very important to the scientist.

\section{Culture and Values, Aesthetics as a Science and Its Subject}

This subchapter provides a brief review of some parts of Niko Chavchavadze's philosophical inheritance. These are: the concepts of culture, values and aesthetics. Marx-Leninism scientific philosophy which was dominant in every branch of Soviet science didn't become the part of the Institute of Philosophy. When Niko Chavchavadze was persecuted ideologically he managed to work on topical issues of philosophy which laid the foundation for new researches of cultural issues.

Niko Chavchavadze began his scientific research classically. First he began to define the terms. At first he defined the concepts of "Culture", "Structure", "Hierarchy" and "Values". He wanted to define these terms in order not to mix different meanings of one term in a scientific text. Accordingly, "culture" referred to everything that cohered values acknowledged by people. "Value" referred to what people strived to as their goal, or the means of achieving their goal. "Structure" referred to the connection between the parts of the whole, and their attitude toward the whole. "Hierarchy" referred to an upward row where every following step was more important than a previous one, and 
the value of each step and the whole row depended on the value of the top $\operatorname{step}^{37}$.

In our opinion, this approach is right scientifically. Indeed, it's impossible to study what is not defined. From this point of view, it is important to separate a research issue from those that are not to be researched. In this case, it is important to separate culture from non-culture. This was a point of Niko Chavchavadze. According to him, in order to answer this question: "What is culture?", first it was necessary not only to research the nature of culture, but also to conduct comparative study of different cultures and define their role in society. It is very important not to mix culture with non-culture to achieve the goal. The concept of culture differs in the fields of philosophy and science that makes the task more difficult. While according to scientific fields, culture is collection of products of human activities, philosophical fields define it as an expression of its inner essence and idea. They try to show the significance and concept of culture. The values of culture are the most important for their research $^{38}$.

It is necessary to define the values to make them vivid. Value is a part of object. For this reason, it must not be mixed with sign. Value is what is valuable to somebody. For this reason, it can't be a real sign of object. While the existence of the characteristics of object depends on object itself, value doesn't depend on material existence or non-existence of object. However, it doesn't mean that value doesn't depend on natural characteristics of its carrier or it is absolutely indifferent to the reality. It is on the contrary. Specific value of any object pends on the natural ontology of its characteristics. The main characteristic of value is that its acting area is human culture and social reality, or products of human activities. Values can be characteristic to the areas of human activities. They can't be characteristic to the natural appearances. In the culture the existence of value is a result of human activities, or the result of such action which is an outcome of free and purpose activity.

There are two kinds of human action which strive to create culture. These are: material-real and ideal. Values were created when a man started to manufacture them. They exist only in the world of culture which is impossible without human actions. The thing is valuable when it calls forth the sense of superiority and becomes a subject of choice. However, it doesn't mean that only

\footnotetext{
37 Чавчавадзе Н., Культура и ценности, Тбилиси, 2007, p. 16-17.

${ }^{38}$ Ibidem, p. 18-22.
} 
those things are valuable that meet the demands of man. Conclusively, there are not only subjective value-means, but also value-goals which are standard for the rest values. Among them are values of concrete individuals whose goal is to strive to supreme values. According to Niko Chavchavadze, supreme value-goals can't be only relative and subjective. It should contain absolute and objective elements as well. Through absolute and relevant dialects it is possible to determine epochal and eternal values. The thing that has epochal importance, or is valuable in a concrete period, covers universal values that transcend a concrete period. Such value is absolute which can lay the foundation for the achievement of fantastic condition in the development of human culture. It is a final and ideal level and cultural society should strive to reach it.

A man's strive to absolute values will be brought out during the study of man's aesthetic attitude toward the reality. According to Niko Chavchavadze, aesthetics is a perception of human activities in all fields in spite of the fact that his subject is the art. It is caused by the fact that creating a piece of art is the highest level of human action. It brings out the elements of aesthetics most vividly. Niko Chavchavadze said: "At a low level of the development, the sides, as well as moments and elements of an event are less differentiated, established or "displayed". The development or rising to higher level means transformation from a diffuse condition to a clearer one. For this reason, it is more reasonable to study every event, including aesthetic, at a high level of its development. In case of passive aesthetic attitude (feeling aesthetic), the sides of this attitude (subjective and objective, formal and conceptual, purpose and purposeless, aesthetic and non-aesthetic) are mixed up. These moments are clearer and more accessible for the study in art, as in the realization of human attitude towards the reality. While passive aesthetic attitude is characteristic only to the feeling and thus, it is an object of self-study, art is "materialized" into pieces of art which are subjects of objective study"39.

Conclusively, according to Niko Chavchavadze, "Aesthetics is a science of art about the realization of a man's aesthetic attitude towards the reality", or "Aesthetics is a science of art about a specific form of reflecting the reality"

As art is an intellectual and emotional reflect of the reality it has a double nature:

\footnotetext{
${ }^{39}$ Idem, Культура и ценности, Тбилиси, 2007. p. 14.

${ }^{40}$ Ibidem, p. 15.
} 
It has been noted many times in Aesthetics that art has a double nature. It is a mixture of two different (and from some point of view, opposite) sides. It has also been noted many times that art and aesthetics is a mixture of sensuous and numinous (Plato, Hegel), or unity of freedom and obligation (Kant), or unity of consciousness and in-consciousness (Schelling), or it doesn't reflect only senses, but also ideas (Plekhanov against Tolstoy) and etc. ${ }^{41}$

Niko Chavchavadze noted that perception can have different natures. In one case it can be cognitive, and in another - aesthetic. While senses and their kinds are not different from one another for cognitive perception, senses and values have different meanings for aesthetic perception. He said:

"The kinds of senses have one meaning in cognitive perception. Senses present us signs of an object. We need them to differentiate and compare different objects. This task can be performed not only by sense of sight and hearing, but also by senses of touch, smell and taste. For instance, a chemist chooses substances not only by color, but mainly by smell and taste. In cognitive perception a sense is a general sign of an object. While it reflects an object's general nature, emotional tone of a sense (or nature inspired by a sense) is not important to perception. The role of senses is different in aesthetic perception. Senses have different meaning and importance here. They reflect signs of an object but it is not the most important. The most important is their emotional tone. Sense is mixed with emotional tone and it is important together with this emotion to aesthetic perception. While black and white have the same importance to cognitive perception, it has absolutely different importance to aesthetic perception. For an artist color is much more than one of the signs of an object. It is known that white color is a sign of innocence. Black is associated with evil and torture. Red is associated with passion and revenge, and violet sadness. As a result of different combinations, the nature of these colors intensifies. They create harmony or contrasts. Senses of color is mixed with its emotional nature in an artist's perception"42.

Values can be classified into two different classes. These are: material and spiritual. This classification is, of course, conditional because a man's demands, no matter they are material (vital) or spiritual can't be strictly differentiating from one another. However, it doesn't mean that these demands are of one category and parts of one culture.

\footnotetext{
${ }^{41}$ Ibidem, p. 31.

${ }^{42}$ Ibidem, p. 33.
} 
Values can conditionally be divided into two big classes. If an object can meet a man's vital demands (for instance, foodstuff or the weapon to get foodstuff) it has material value. If an object meets a man's highest spiritual demands it has spiritual value. The classification of values is conditional because empirically a man's vital and spiritual demands are not differentiated from one another. They are usually combined. Anyway, a man's vital demands are not primitive demands. Public life made them soft and human and thus, involved elements of spiritual demands in it (For instance, a man doesn't eat meet first of all because it is immoral and then, because it is physiologically unacceptable and abhorrent). However, how much combined material and spiritual demands are, they are still demands of different categories. This difference is shown by the concepts of material and spiritual culture. They are parts of one culture. Material and spiritual cultures differentiate only in abstraction. However, nobody mixes them up. While the concept of material culture refers to everything that is created by a man to meet his material demands, the concept of spiritual culture refers to everything that is created to meet a man's spiritual demands ${ }^{43}$.

Niko Chavchavadze thought that the attitude between the concepts of spiritual values and useful was very interesting. Although everything that is useful is very important for the existence of man, none of spiritual values is similar to usefulness. It can be explained by the fact that spiritual value is a value of higher content:

None of spiritual value is boiled down to usefulness. It can be explained by the fact that these values are of higher categories. At the first glance, it contradicts the idea about the role of consciousness in the process of practice. Consciousness appeared and developed in the process of practice. All its aspects were in the service of practice, or utilitarianism. First was utilitarianism and later, other values were created. Now it is stressed that original value of truth, kindness and beauty precedes the opportunity to use them for practical and utilitarian goals. Although contradiction is obvious, it is all show. For instance, it is wrong that first man had useful idea and then, it was converted into the truth. The idea was true from the beginning but man looked at it from utilitarian point of view and later, he appraised its truth. It is wrong that the attitude and behavior towards events were first useful and later, they acquired a sign of

\footnotetext{
${ }^{43}$ Ibidem, p. 167-168.
} 
the truth. They had a sign of the truth from the very beginning but man could not notice it. Later, he was able to appreciate it ${ }^{44}$.

Noteworthy is that the word "useful" can be used not only in its narrow utilitarian sense, but also in its broad one. According to Niko Chavchavadze, when this word is used in its broad sense it covers the whole sphere of values. Everything that is aesthetic is valuable. However, it is absolutely inacceptable to use it in its utilitarian sense. Niko Chavchavadze said: "Noteworthy is one more thing to find out the attitude between useful and aesthetics. The word "useful" is not used only in its narrow utilitarian sense, but also in its wide sense. For instance, we can speak about usefulness of a tragedy which can have lustral and luminous effect. Sometimes it is said that something is useful not only for an individual, but also for the whole family. From this point of view, aesthetics, ethics and cognition is useful because such values make a man to be a man. However, this meaning of "useful" covers the whole sphere of values. Nobody argues that aesthetic is valuable. It is arguable and inacceptable to use this value in its utilitarian sense, or to call it means of meeting material demands. Value of aesthetics is a spiritual value" ${ }^{35}$.

Niko Chavchavadze noted that an aesthetic subject has two layers. These are: front and back. A front layer is perceptible. It is sensuous and gives opportunity for aesthetic appraisal. Besides, it has in-sensuous deep content which makes aesthetic perception different from universal perception: "An aesthetic subject must have sensuous, perceptible front layer. A subject that is not perceptible can't be aesthetic. Although sometimes there are talks about the beauty of some theories, ideas or spiritual content, this case concept of beauty is used in its figurative sense (ethical), not the beauty of the idea or theory itself as an intelligible object is meant, but the beauty of its sensuous imaginary icon. [...] On the other hand, a front layer of an aesthetic object must have its in-sensuous deep content because without it perception of aesthetics will be equal to the universal perception, and an aesthetic object will be equal to a sensuous, facial layer of an empirical object. Consequently, sensuous, front layer is a form through which deep content of an aesthetic object becomes clear"46.

Back layer of an aesthetic object consists of all attitudes and connections that a man has towards the reality. However, it doesn't mean that content of an

\footnotetext{
${ }^{44}$ Ibidem, p. 173-174.

${ }^{45}$ Ibidem, p. 175.

${ }^{46}$ N. Chavchavadze N., The Issues of Aesthetics, vol. 1, Tbilisi 2007, p. 20-21.
} 
aesthetic object is a mechanical sum of these elements. They lose their first face and acquire a new and altered face.

"A 'back layer' of an aesthetic object has very difficult structure. It consists of many elements, including all attitudes and connections of a man to the reality. However, content of an aesthetic object is not a sum of these elements. These elements lost their first face in this content. They must be changed to become elements of content of an aesthetic object" ${ }^{\prime 2}$.

In conclusion, this article provided a brief survey of key issues of Niko Chavchavadze's philosophical inheritance. The concepts of culture, structure, value and hierarchy, as well as aesthetics as a science, its object of survey, nature of aesthetics, its characteristics and distinctive features, and structure of aesthetic object is a part of those interesting issues that were studied by the philosopher. His work is a bridge across the river connecting two shores with one another. His different and original study laid the foundation for future important studies which were conducted in the Institute of Philosophy of the Georgian National Academy of Sciences. A scientific bridge which Niko Chavchavadze managed to construct between two periods of science during his scientific activity, turned out to be connection between concepts, doctrines and ideas. Niko Chavchavadze's philosophical inheritance needs much deeper analyze. It is not the goal of this article. We hope that our work will pave the way to those future scientists whose goal is to study various works of very interesting and original scientist and philosopher Niko Chavchavadze.

\section{Bibliography}

Alsina Clota J., El Neoplatonismo: síntesis del espiritualismo antiguo, Anthropos, Barcelona 1989.

Арендт Х., Между прошлым и будущим. Восемь упражнений в политической мысли, Издательство Института Гайдара, Москва 2014.

Balanchivadze R., "A Genuine Philosopher/Academician Niko Chavchavadzel", In the collection: Philosophical and Publicistic Letter/ Greetings, Memoirs/, Publishing house "Universal", Tbilisi 2011, p. 173-190.

Ballart P., Eironeia. La figuración irónica en el discurso literario moderno, Quaderns Crema, Barcelona 1994.

${ }^{47}$ Ibidem, p. 27. 
Bertorello A., Bajtín: acontecimiento y lenguaje, "Signa” 2009, no. 18, p. 131-157.

Biemel W., La ironía romántica y la filosofía del idealismo alemán, "Convivium" 1962, no. 13-14, p. 29-48.

Booth W., A Rhetorics of Irony, The University of Chicago Press, Chicago 1974.

Buachidze T., A Genuine Intellectual, In the collection: Philosophical Essays, II, Tbilisi 2005, p. 644-649.

Чаадаев П., Философические письма, Римис, Москва 2011.

Чавчавадзе Н., Культура и ценности, Тбилиси, 2007.

Chavchavadze N., I don't have a right not to be an optimist, "Kvareli" 1989, no. 100 (6108), p. 2.

Chavchavadze N., Let us not stay bolts, “Tbilisi” 1990, no. 183 (11302), p. 5.

Chavchavadze N., One round of the fight for the national-liberation movement failed, "Iveria Express" 1994, no. 30 (251), p. 2.

Chavchavadze N., For the nature of the subject of Aesthetics, vol. 2, Tbilisi 2007a.

Chavchavadze N., The Issues of Aesthetics, vol. 1, Tbilisi 2007.

Chico Rico F., La traducción del texto filosófico: entre la literatura y la ciencia, "Castilla. Estudios de Literatura" 2015, vol. 6, p. 94-112.

Colli G., El nacimiento de la filosofía, Tusquets Editores, Barcelona 2009.

Del Pino Cabello J. M., Algunas observaciones sobre el neoplatonismo becqueriano, "Dicenda. Cuadernos de filología hispánica" 1986, no. 5, p. 91-101.

Descartes R., Discurso del método. Meditaciones metafísicas, Espasa-Calpe, Madrid 1970. Garrido Gallardo M. Á., IRONÍA. Gran Enciclopedia Cervantina, ed. by C. Alvar, VII., Castalia, Madrid 2010.

Guillén C., De influencias y convenciones, 1616, "Anuario de la Sociedad Española de Literatura General y Comparada” 1979, vol. II, p. 87-97.

Jankélévitch V., L'ironie, Flammarion, Paris 1964.

Kierkegraard S., De los papeles de alguien que todavía vive. Sobre el concepto de ironía, Editorial Trotta, Madrid 2006.

Lampis M., Del texto a la cultura. Apuntes sobre el pensamiento sistémico aplicado a los estudios culturales, "Signa" 2013, no. 22, p. 447-462.

Lisi F. L., La traducción de los textos filosóficos clásicos. En VV.AA., Primer Simposio Internacional Interdisciplinario "Aduanas del Conocimiento". La traducción y la constitución de las disciplinas entre el Centenario y el Bicentenario. Residencia Serrana IOSE, La Falda, Córdoba, Argentina. 8 al 12 de noviembre de 2010, Universidad de Córdoba, Córdoba 2010, p. 1-14.

Luarsabishvili V., La sensación de la soledad en las Rimas de Bécquer (Aproximación a la poesía metafísica), "Revista de filosofía" 2017, no. 42 (2), 247-259.

Marías J., Ideas de la metafísica, Editorial Columba, Buenos Aires 1954.

Moreno Hernández C., Notas sobre Bécquer: Materialismo y Romanticismo, "Castilla. Estudios de literatura" 1987,12 , p. 95-106. 
Morón Arroyo C., La ironía en el Quijote: la maestría de la obra maestra, Actas del Congreso Cervantes, El Quijote y Andalucía (Sevilla 6-8 de mayo de 2005), Asociación Andaluza de Profesores de Español, Sevilla 2007, p. 111-136.

Mtibelashvili T., Philosophy of Culture, In the collection: The History of the Georgian Philosophical Ideology, IV, Tbilisi 2003, p. 397-434.

Solana Dueso J., La filosofía griega en el siglo XXI, "Daímon. Revista Internacional de Filosofía" 2010, no. 50, p. 169-178.

Unamuno M. de, Del sentimiento trágico de la vida, Espasa Libros, Madrid 2011.

Wolfsdorf, D., The irony of Socrates, "The Journal of Aesthetics and Art Criticism" 2007, no. 65 , p. $175-187$.

\section{Zusammenfassung}

\section{Der Philosoph Niko Chavchavadze: Leben und Werk}

Der Artikel behandelt den Philosophen Niko Chavchavadze. Er war eine der bedeutendsten Persönlichkeiten seiner Generation. Das Hauptziel von Chavchavadze war es, neue Forschungsrichtungen in der Philosophie aufzudecken. Der Artikel bietet eine Übersicht über sein philosophisches Erbe. Untersucht wird der Entwurf der Kultur und der Werte sowie ihre Struktur und Hierarchie. Darüber hinaus wird die Ästhetik als Gegenstand der Wissenschaft dargestellt.

Schlüsselworte: Niko Chavchavadze, Kultur und Werte, Georgische Sozialistische Sowjetrepublik, Philosophie

\section{Streszczenie}

\section{Filozof Niko Chavchavadze: życie i dzieło}

Tematem artykułu jest Niko Chavchavadze jako filozof. Był jedną z najbardziej znaczących postaci swego pokolenia. Głównym celem Chavchavadze było znalezienie nowych kierunków badań w filozofii. Artykuł stanowi przegląd jego spuścizny filozoficznej. Analizowana jest koncepcja kultury i wartości, jak również ich struktura i hierarchia. Ponadto, naszkicowana zostaje jest estetyka jako przedmiot nauki.

Słowa kluczowe: Niko Chavchavadze, kultura i wartości, Gruzińska Socjalistyczna Republika Radziecka, filozofia 
Information about Author:

VLADIMER LUARSABISHVILI, doktor (doktorat w Madrid Autonomous University), profesor na Wydziale Polityki i Stosunków Międzynarodowych w New Vision University, Tbilisi; adres do korespondencji: New Vision University, la Evgeni Mikeladze St., 0159, Tbilisi, Georgia; e-mail: vluarsabishvili@newvision.ge 